\title{
Proto-historic Background of Martial Arts Schools in Eastern Japan
}

\author{
Takamune KAWASHIMA*
}

\begin{abstract}
Kashima city is best known for having the oldest martial arts schools in Japan. While some of its martial arts schools, such as the Kashima Shinryū, were officially established in the latter half of the medieval period, there was already a long tradition of martial arts in Kashima region since the Kofun period (the fourth to the seventh centuries AD). This paper focuses on archaeological remains and the landscape around the Kashima Grand Shrine, to clarify the significance and influence of the Kashima Grand Shrine in managing the eastern part of the territory of ancient Japan. This paper examines some characteristics of the region, such as its coastal location that enabled the transportation of materials and soldiers. Another specific aspect of the place could be the advanced metal production evident in the giant sword of the Kashima Grand Shrine made in the early ancient period. Ancient workshops for metallurgy were found at the former local government office in Hitachi-no-kuni, the area of today's Ibaraki Prefecture. It thus seems no coincidence that Kashima was chosen as a kind of military base. The archaeological findings that have been made in this location provide many reasons why the lineages of various martial arts schools, including the Kashima Shinryū, derived from this city, which led to the formation of later bushi groups in the medieval period of eastern Japan.
\end{abstract}

Keywords: ancient history, Kashima, archaeology, martial arts, logistics

\section{Proto-zgodovinsko ozadje šol borilnih veščin na vzhodu Japonske}

\section{Izvleček}

Mesto Kashima je znano po najstarejših šolah borilnih veščin na Japonskem. Nekatere šole borilnih veščin, kot je Kashima Shinryū, so ustanovili šele proti koncu srednjeveškega obdobja, vendar v kašimski regiji tradicija borilnih veščin sega vse do obdobja Kofun (od četrtega do sedmega stoletja našega štetja). Prispevek obravnava arheološke ostanke in pokrajino $\mathrm{z}$ glavnim svetiščem Kashima $\mathrm{v}$ središču in pojasnjuje vpliv tega svetišča na upravljanje vzhodnega ozemlja antične Japonske. Opozori tudi na nekatere značilnosti regije, na primer na bližino obale, kar je omogočalo prevoz materiala in vojakov.

Še ena pomembna značilnost tega prostora je napredna kovinarska proizvodnja, ki se med drugim kaže v velikanskem meču velikega svetišča Kashima iz zgodnjega antičnega

Takamune KAWASHIMA, PhD,

Shimane University, Japan.

k.takamune[at]gmail.com

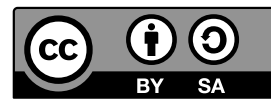


obdobja. Starodavne delavnice za metalurgijo so našli v nekdanjih uradih lokalnih vlad v Hitachi-no-kuni na območju današnje prefekture Ibaraki - zato verjetno ni naključje, da je bila Kashima izbrana za vojaško bazo. Arheološke najdbe s tega območja ponujajo odgovore na številna vprašanja, na primer zakaj so prav v tem mestu nastale različne šole borilnih veščin, vključno s Kashima Shinryū, kar je pripeljalo do nastanka poznejših skupin bushijev v srednjeveškem obdobju na vzhodu Japonske.

Ključne besede: antična zgodovina, Kashima, arheologija, borilne veščine, logistika

\section{Introduction}

Kashima is best known as the birthplace of martial arts in Japan. While martial arts schools such as Kashima Shinryū were officially established in the latter half of the medieval period, there was already a long tradition of such schools in the Kashima region, starting in the Kofun period (Table 1). This paper focuses on archaeological remains and the landscape around the Kashima Grand Shrine, to clarify its significance and influence in managing the eastern part of the territory of ancient Japan. I will examine some characteristics of the region, such as its coastal location that enabled the transportation of materials and soldiers. Another specific aspect of the place could be the production and working of metal, as represented by the legendary giant sword associated with this location. Ancient workshops for metallurgy have been found near the former local government office in Hitachi-no-kuni, the area of today's Kashima. Such archaeological findings indicate the possible reasons why the lineages of various martial arts schools, including Kashima Shinryū, originated from Kashima, which might have led to the formation of bushi of the eastern Japan, i.e. toggoku bushidan in the medieval period.

Table 1 Brief chronology in eastern Japan mentioned in the text

\begin{tabular}{|l|c|}
\hline Period & Date \\
\hline Kofun & ca. AD 300-600/700 \\
\hline Nara & $710-794$ \\
\hline Heian & $794-1,185$ \\
\hline
\end{tabular}

While the accounts on the origin of martial arts schools in Japan appear in historical texts, the description of Kashima as the "birth place of martial arts in Japan" was mostly based on legendary records. To clarify the Kashima's connection to martial arts, I examine its geographical position and distribution of archaeological sites, which were involved in military action in the pre- and proto-historic periods (the fifth to the ninth centuries AD), and then reflect on the existing regional historical records. 


\section{Eastern Japan in the Ancient Period}

Geographically, Kashima is located by the Kasumigaura Lake, which enabled transport to inland areas such as the governmental office of Hitachi-no-kuni in the city of Ishioka (Figure 1). In the ancient period, Kasumigaura Lake was an inner bay, which was connected to important rivers such as the Kinu which runs through the northern Kantō Plain. This inner bay and rivers functioned as routes for the transportation of goods between inland and coastal areas.

The political centre during the Kofun and Heian periods (the third to the twelfth centuries) was in the Kinki area around Nara and Kyōto. In the seventh century, because of the newly centralised political system influenced by Chinese laws, there were only a few mounded tombs constructed in the Kinki area. On the other hand, in the northern part of the Kantō Plain, which was under the control of the central government in Kinki, the construction of large-scale mounded tombs was at its highest. In such tombs many grave goods relating to military power, such as long swords, have often been found.

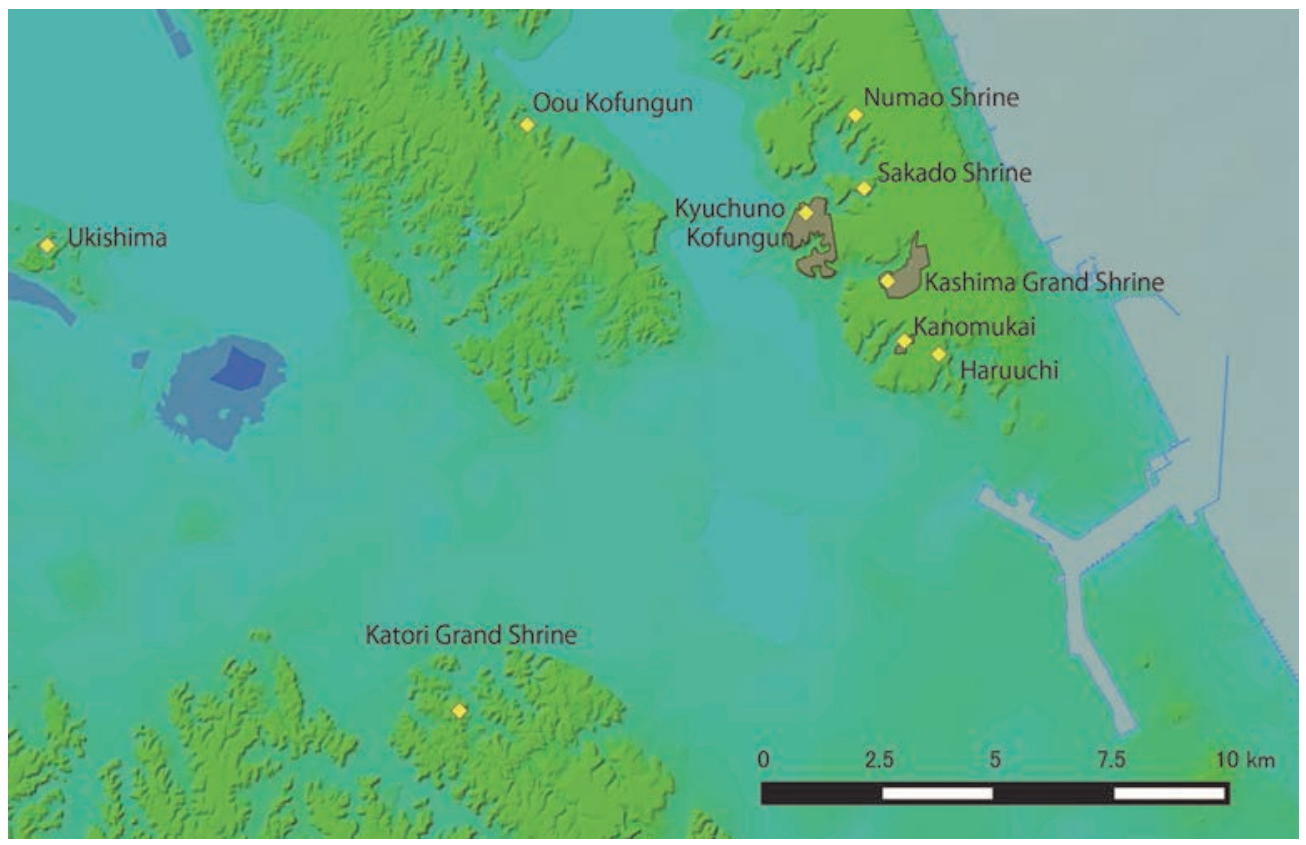

Figure 1: Sbrines and archaeological sites mentioned in this article (modifeed from GSI Tiles; bathymetric contours are derived from data produced by JHOD)

Two large-scale mounded tomb clusters are known around the Kashima Grand Shrine: Kyūchūno (Ishibashi et al. 2006) and Oou (Itakochōshi hensaniinkai 
1996). The Kyūchūno mounded tomb cluster is two kilometres north from the Kashima Grand Shrine, consisting of 127 mounded tombs, which were constructed from the end of the fourth to the middle of the seventh centuries (Itokawa 2017) (Figure 1). A typical keyhole-shaped mounded tomb, a symbol of a powerful chief, was also included in this cluster. Meotozuka Kofun, constructed in the latter half of the sixth century, is $107.5 \mathrm{~m}$ long and $34 \mathrm{~m}$ wide, with a circumferential ditch, which was one of the largest mounded tombs in the Late Kofun period. In the first half of the seventh century, a $97 \mathrm{~m}$ long scallop-shaped Ōtsuka mounded tomb was constructed.

The mounded tombs of the eastern area were rich in weapons and horse harnesses as burial goods, which suggests that powerful local families were engaged in conflicts, especially with the tribal groups from northern Tōhoku, called Emishi (Figure 2). One such family was the Nakatomi clan, which is considered the founder of the Kashima Grand Shrine. According to historical texts, such as Hitachi-no-kuni Fudoki from AD 721, (Akimoto 2001; Aoki 1997), the Nakatomi clan had extended their political power to the area of Kashima. The famous founder of Japanese martial arts, Kuninazu no Mahito (Seki 2015, 2), is thought to have belonged to the fourth generation of the Nakatomi family after their occupation of Kashima. According to the Nakatomi family tree, Kuninazu no Mahito could have lived around 500 $\mathrm{AD}$, from the end of the Middle to the beginning of the Late Kofun period, which means that he might have been buried in a mounded tomb of the Kofun period. While there are no Middle Kofun mounded tombs in the Kyūchūno mounded tomb cluster, and it is not clear if the Kyūchūno mounded tomb cluster was constructed by the Nakatomi family, archaeologists assume that the family or others in their lineage made them. Although the descriptions in the historical texts such as Hitachi-no-kuni Fudoki need to be critically assessed, the general trends mentioned above, such as establishment of shrines and development of metallurgy, are supported by the archaeological evidence. Overall, the method used in this research mainly relies on considering the archaeological remains.

\section{The Establishment of the Kashima Grand Shrine}

As mentioned above, in contrast to Kinai region, where large mounded tomb construction faded, in the Kantō region such tombs were still built in the seventh century. However, the use of mounded tombs as a symbol of a particular lineage were soon replaced by temples, which became new symbols of political power. Temples were built in local capitals in each area and became symbols of state formation, i.e., the ritsuryō system. As no remains or workshops related to military equipment 


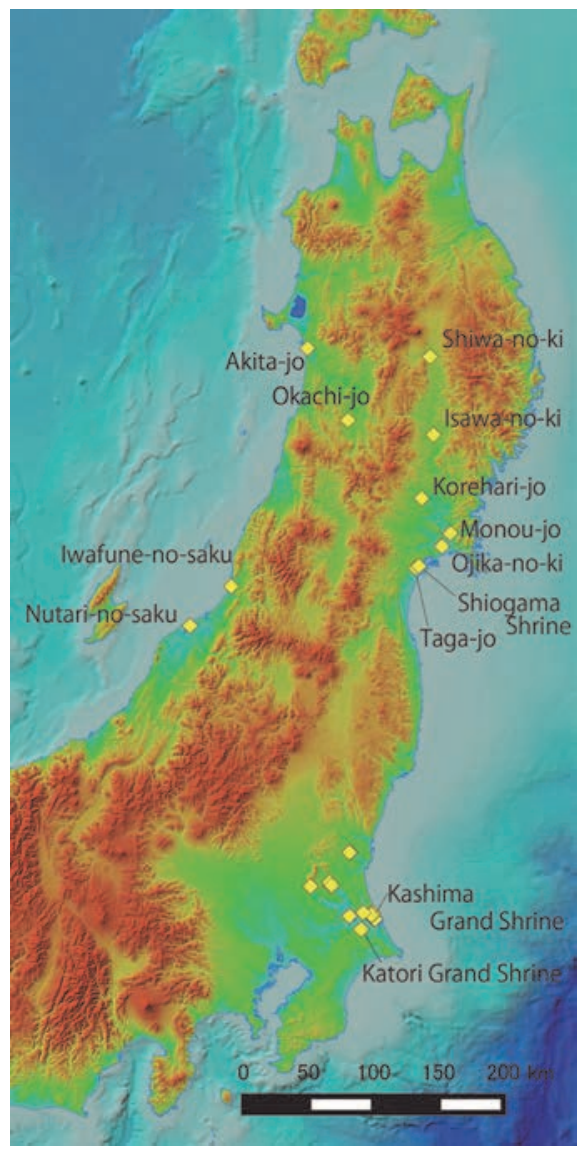

Figure 2: Major ancient castles in eastern Japan (modified from GSI Tiles; bathymetric contours are derived from data produced by JHOD)

have been found at these ancient temples, it is assumed that they were established for the purpose of spiritual protection of the nation. In contrast to Buddhist temples, Shintō shrines associated with various myths seem to have been connected to the military, especially during their foundation.

In the seventh century, the central government in Kinai was established and could control most areas in the Japanese archipelago, except Hokkaidō, Tōhoku and the Ryūkyū islands. In spite of the distribution of the mounded tombs in the Tòhoku region, most of the area was not under control of the central government. The government expanded its territory northwards, which led to conflict with the northern groups (Friday 1997). In fact, several important fortresses were constructed in the eighth century on both the Pacific and the Japan Sea sides of the nation (Figure 2). 
The border of the central government's territory was the southern edge of the present Tōhoku district, so the Hitachi-no-kuni, including Kashima, was located on the front line. Although Hitachi-no-kuni accepted the new political system with Buddhist temples, there were some regional differences in the locations used for building temples in Hitachi-no-kuni (Inada and Sasaki 2013). The distance between temples and mounded tombs could represent local powerful families' attitudes towards building temples. While some district offices were located apart from the mounded tombs of former powerful families in the sixth century, the Kashima and Daiwatari temples and district offices were built relatively nearby mounded tombs. Both areas are facing the Pacific Ocean and located at the mouths of large rivers, which implies that such geopolitically important locations were controlled by political powers connected with the central government. As noted above, while temples were usually built in each district, in Kashima, on the other hand, the Kashima Grand Shrine was constructed as one of the important shrines.
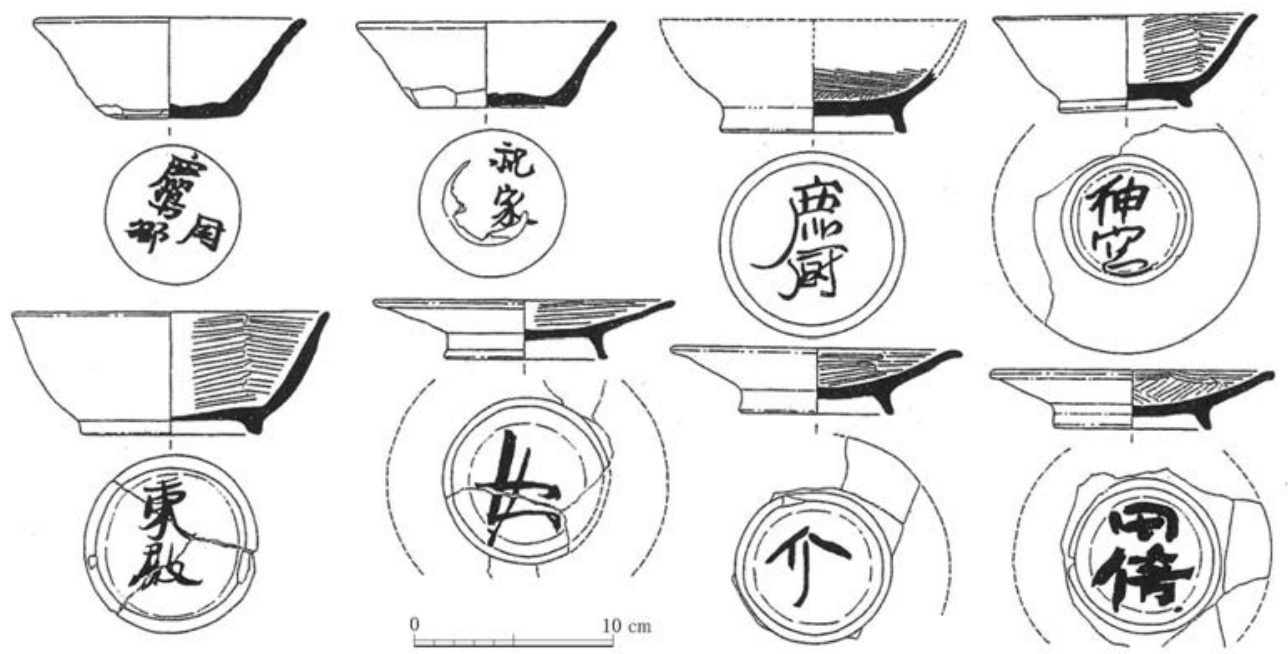

Figure 3: Pottery with ink writing at Kanomukai (modified from Honda 1994, Figure 6)

The Nakatomi family initiated the central government's decision in 649 AD to dedicate a wide area surrounding the present Kashima Grand Shrine and the Kyūchūno mounded tomb cluster as the kamigoori, special land for a shrine. Although it is not clear if the clan who made the mounded tombs was also directly involved in the establishment of the Kashima Grand Shrine, we may assume that they played an important role as they were governing the kamigoori area. According to Hitachi-no-kuni Fudoki, the kamigoori in the Kashima area was 
established at almost the same time as in the Katori Shrine area. This means that the tax from Kashima area was dedicated to the shrine, which led to the official establishment of the Kashima Grand Shrine. These dates are supported by the archaeological remains from the latter half of the seventh century found at the Kashima Grand Shrine (Itokawa 2017). According to descriptions about the kamigoori in Hitachi-no-kuni Fudoki, we know that at least one shrine building existed in this area, and thus the origin of the Kashima Grand Shrine was established already in the first half of the seventh century. After the eight century, the shrine developed into its present appearance. In Kashima, the Kanomukai site was regarded as Kashima district office $(g \bar{u} k e), 1.5 \mathrm{~km}$ south from the Kashima Grand Shine, which was relatively large, compared with other district offices (Kashima City Board of Education and Culture and Sports Kashima City Promotion Foundation 2016). Excavations have found pottery with ink writing, which suggests the presence of a shrine (jingī), priest (bafuriya/hafurike) and kitchen (kuriya) (Figure 3).

\section{Distribution of Military Workshops}

\section{Iron Workshops}

Governmental iron workshops were established near Hitachi-no-kuni provincial office, the Kanoko C site in Ishioka, Ibaraki. The size of the site is assumed to be $240 \mathrm{~m}$ by $240 \mathrm{~m}$, containing regularly arranged postholes for buildings, pit buildings as various workshops for making weapons, and lines of fences (Kawai 1985; Kawai and Satō 1983). Most features were made around 900 AD. The site had one of the largest iron workshop complexes at that time. According to the size and the location, Kanoko $\mathrm{C}$ seems to have functioned as a governmental iron smelting workshop (Kawai 1985).

On the other hand, perhaps because there have been fewer excavations, only a few iron workshops from the eighth century have been found in Kashima (Akutsu 1985), although it is possible to find some from this time (Figure 4).

Based on the description of iron smelting in Hitachi-no-kuni Fudoki, there were more than 20 iron workshops around Kashima. At the construction of the office building of the Kashima Grand Shrine, iron workshops which operated in the latter half of the eighth century were found (Itokawa 2017). In spite of plentiful, iron sand and forests for fuel that were in the area, according to Hitachi-no-kuni Fudoki, it was prohibited to collect iron sand and pine trees around the Kashima Grand Shrine. 


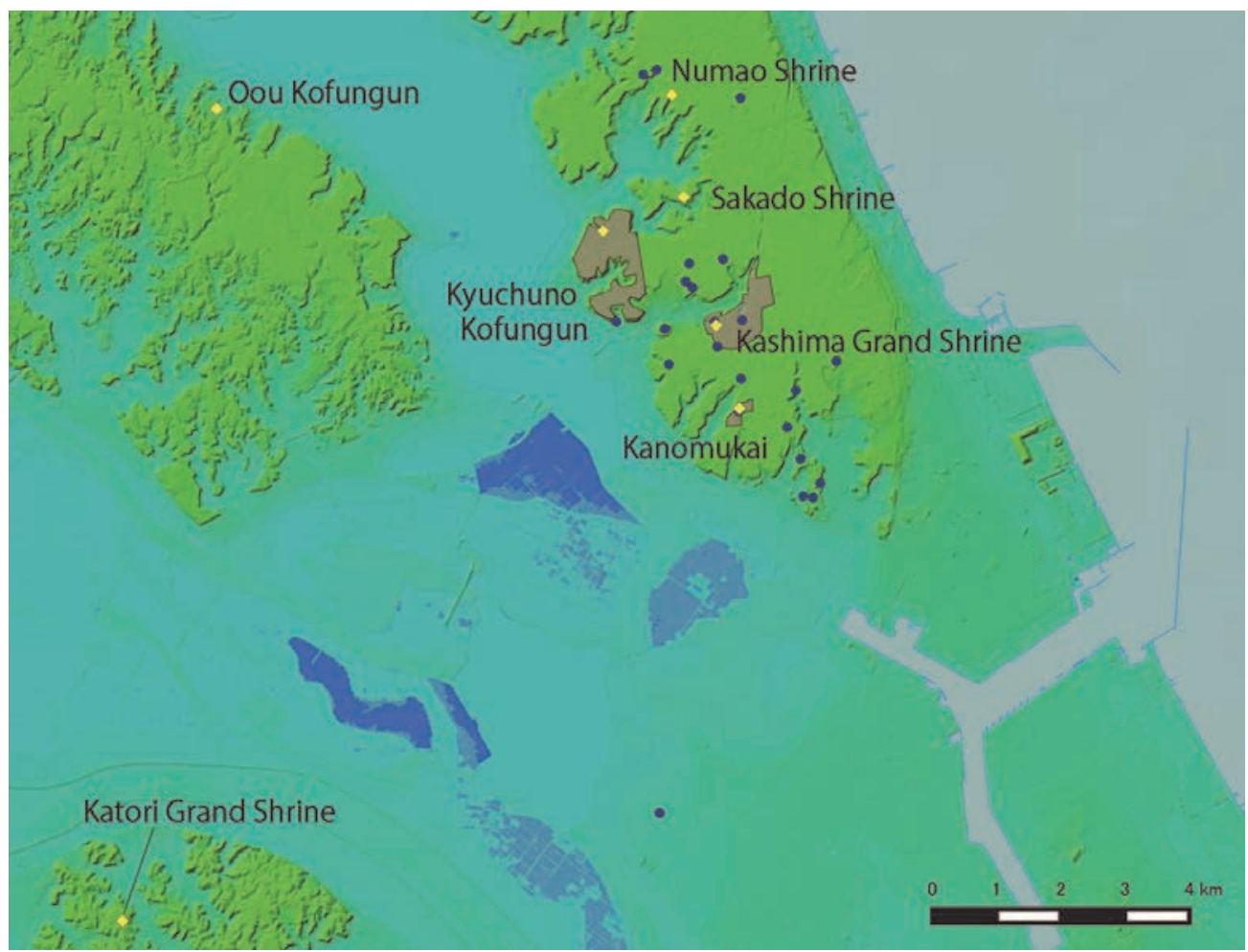

Figure 4: Distribution of ancient iron workshops around Kashima (blue circles) (modified from GSI Tiles; bathymetric contours are derived from data by JHOD)

\section{Salt Production}

Another important military supply was salt, which was derived from seawater in Japan. Until the 11th century, salt pottery was mainly used for boiling down brine to obtain crystalized edible salt. In the Manyōshü a number of areas are mentioned for salt-making, such as Ukishima, also known as the place where salt was first produced in the Jōmon period (Kawashima 2015; in press). However, the Final Jōmon salt pottery has not been found around Kasumigaura Lake or Ukishima, which contradicts the description in Hitachi-no-kuni Fudoki. This can probably be explained by the introduction of the iron pan (Tao 2009, 314). Iron salt making pans appeared in texts written in the early eighth century, such as Suö-no-kuni Shözeichō and Nagato-no-kuni Shözeichō. Although there is no mention of iron pans in Hitachi-no-kuni Fudoki, the use of such pans should be considered as explaining why no such pottery has been found here. 


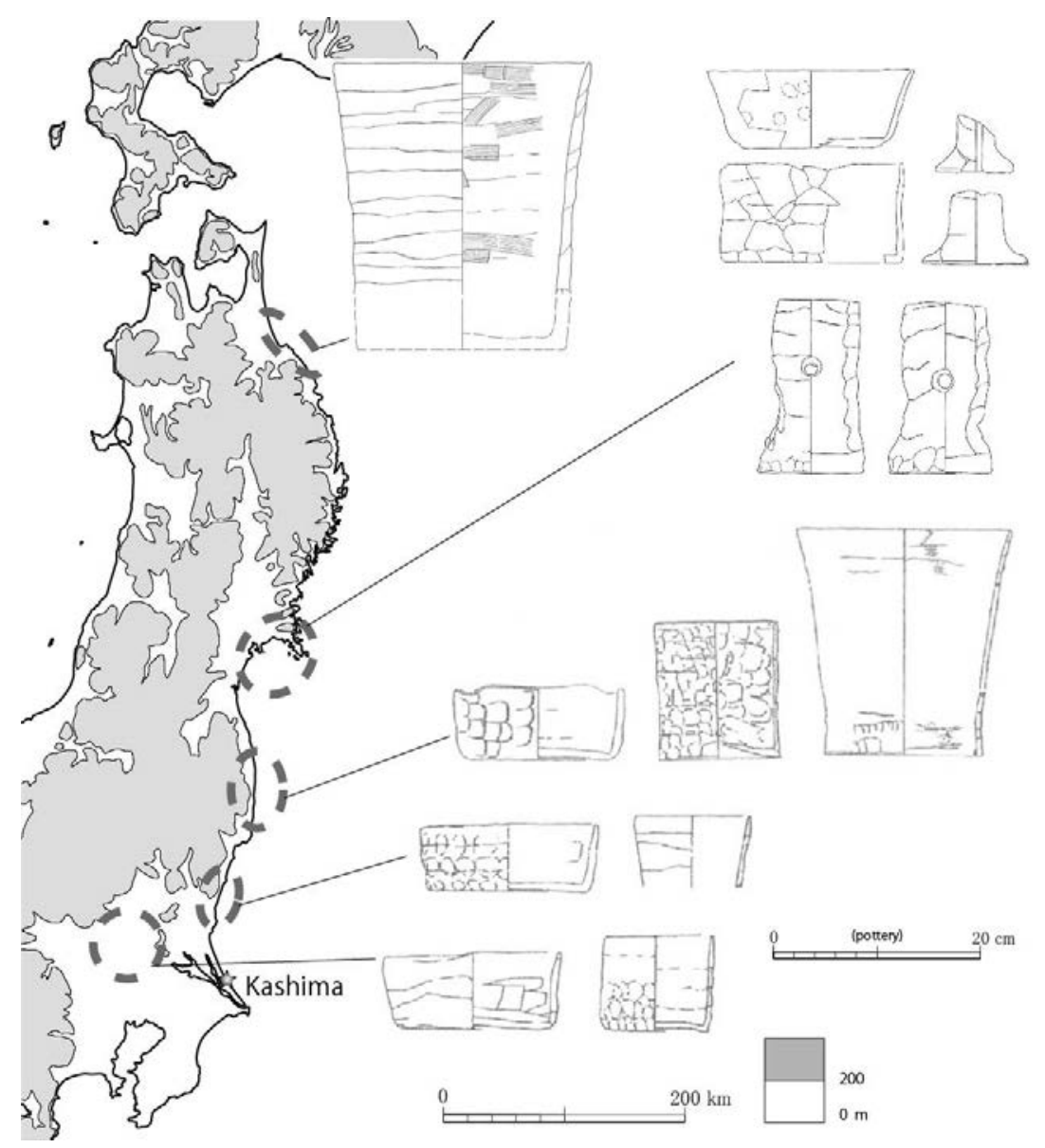

Figure 5: Major areas for ancient salt making in eastern Japan (modified from Kawashima (in press) and Tao 2009, Figure 11)

On the other hand, in the northern part of Ibaraki Prefecture, salt pottery could have been used for salt-making in the eighth to ninth centuries, while most pottery shards were found in houses and thus such objects were probably related to the culinary uses (Kawamata 2014). This pottery has similarities in its shape to that used around the Tagajo fortress in Miyagi prefecture (Figure 5), which implies a continuous relationship between the Miyagi and Ibaraki coastal areas. However, in spite of the local salt production in both Ibaraki and Miyagi prefectures, the amount of salt produced seems insufficient to fully supply the Tagajō fortress (Tao 2009, 314). As the salt made in Miyagi prefecture was almost entirely consumed by the local people, salt as military supply had to be transported from western and central Japan. 
Considering the amount of salt produced and the similarity in salt pottery between Miyagi and Ibaraki prefectures, the demand for salt in the northern frontier, Kashima, could have been connected to the supply in northern Japan.

\section{Location of Ancient Kashima}

These military supplies were especially needed in the period from the end of the eighth to the beginning of ninth centuries (780-811). Kashima was connected by the Kinugawa River to Hitachi provincial office and Kanoko C, a large workshop site by Kasumigaura Lake and to other major places in Hitachi, such as Shimōsa and Shimotsuke. The former path of the Tone River, which ran near the Kinu River, could be used for the transport of supplies and soldiers. Thus Kashima's location was favourable for transport and production. The biography of the Shiogama Shrine, which is close to the Tagajo fortress, describes the relationship between Kashima and Shiogama. Shiogama Shrine worships a deity Shiotsuchi-no-oji, who according to the Nibon shoki and Kojiki was believed to have given important advice to other deities and early emperors. Shiotsuchi-no-oji was said to have guided Takemikazuchi-no-mikoto and Futsunushi-no-mikoto from the Kashima and Katori areas to northern Japan. As Shiotsuchi-no-oji is regarded not only as a deity for salt-making, but also as a maritime one, transportation by ship could have played a strategic role in controlling northern Japan. As Yamaji (2017) asserted, in the latter half of eighth century the central government could have recognised the importance of maritime transportation and the logistical advantages of the area of Kashima and Katori.

\section{Conclusion}

Most ancient provinces were organised based on the land ruling system from the end of the Kofun period. However, Kashima kamigoori established in the seventh century was strongly connected with the central government and the Nakatomi family. As seen in the abundant military grave goods buried in mounded tombs constructed in the seventh century, Hitachi-no-kuni was an important area from the viewpoint of military operations. This was because military supplies such as iron and salt were needed in battles against northern tribal groups.

Kashima has long been famous for the abundance of iron sand and pine trees that were used for fuel, as written in Hitachi-no-kuni Fudoki. However, while some traces of iron smelting from the eighth century were found in the Kashima Grand Shrine, large-scale iron workshops were found at Kanoko C around the Hitachi district office in Ishioka. Kanoko C provided weapons for combat 
against the northern tribal groups, especially from the end of eighth century to the early ninth century.

The archaeological evidence and historical records, such as Hitachi-no-kuni Fudoki, suggest that Kashima was not a place for weapons production. Instead, Kashima has long been seen as the birthplace of martial arts of Japan. Considering the function of early Buddhist temples in Japan and the character of the worshipped deity Takemikazuchi-no-mikoto at the Kashima Grand Shrine, the shrine took the initiative with regard to warfare in both ideological and spiritual ways.

The location of shrines was very important for logistics. Therefore, the Kashima Grand Shrine was built at the river mouth of Kasumigaura Lake. Besides the Kashima Grand Shrine, the kamigoori for the Katori Shrine was established on the southern side of the Kasumigaura Lake. The deity worshipped at the Katori Shrine was also related to martiality, and was described in the Nibon shoki and Kojiki as having a strong connection to Takemikazuchi-no-mikoto. The two shrines established by the central governmental power could control the entrance of the bay, which enabled the central government to transport military supplies from the Kantō to the Tōhoku region by ship.

As the Shintō shrines played an important role in providing the religious and philosophical base for establishing the system of martial arts in proto-history, it might be possible to say that some of the earliest formations concerning the values and the right conduct of bushi were originally invented in the Kanto region, especially in the area around Kashima.

\section{References}

Akimoto, Yoshinori 秋本吉徳. 2001. Hitachinokuni fudoki zenyakuchū 常陸国風 土記全訳注 (A Translation of Hitachinokuni fudoki). Kodansha: Tokyo.

Akutsu, Hisashi 阿久津久. 1985. “Kashima no seitetsu: wakamatsu no hama no tetsu to ken 鹿島の製鉄 : 若松の濱の鐵と剣 (Iron Manufacture in Kashima: Iron and Sword at Wakamatsu Beach)." Etonosu 28: 117-26.

Aoki, Y. Michiko. 1997. Records of Wind and Earth: A Translation of Fudoki with Introduction and Commentaries. Monograph and Occasional Papers Series 53. Ann Arbor: Association for Asian Studies.

Friday, F. Karl. 1997. "Pushing beyond the Pale: The Yamato Conquest of the Emishi and Northern Japan.” Journal of Japanese Studies 23 (1): 1-24. Accessed June 10, 2018. doi:10.2307/133122.

Geospatial Information Authority of Japan (GSI) GSI Tiles. Accessed May 18, 2018. https://maps.gsi.go.jp/development/ichiran.html\#relief. 
Honda, Tsutomu 本田勉. 1994. “Kashima no gunga 鹿島の郡衙 (Ancient District Offices in Kashima)." In Fudoki no kōkogaku 1 Hitachinokuni fudoki no Maki 風土記の考古学 1 常陸国風土記の巻 (Archaeological Study of Fudoki, 1 Hitachinokuni Fudoki), edited by Masahiro Mogi 茂木雅博, 221-43. Tokyo: Dōseisha.

Inada, Kenichi 稲田健一, and Sasaki Kenichi 佐々木憲一.2013. “Hitachinokuni no 7 seiki: Kofun wo chūshin ni 常陸の国の7世紀 : 古墳を中心に (Hitachi Province in the 7th Century)." In Kofun kara jiin he: kantō no 7 seiki wo kangaeru 古墳から寺院へ〜関東の7世紀を考える〜 (From Mounded Tombs to Temples: Reconsideration of the Kanto District of the 7th Century), edited by Saburō Kobayashi 小林三郎 and Kenichi Sasaki 佐々木憲一, 129-39. Tokyo: Rokuichishobō.

Ishibashi, Miwako 石售美和子, Ozawa Takehiro 小澤竹博, and Odashiro Akimaru 小田代昭丸. 2006. Kyūchūno kofungun bunpu chōsa 宮中野古墳群分布 調査 (A General Survey of Kyüchūno Mounded Tombs). Kashimashi no bunkazai 120. Kashima: Kashima City Board of Education.

Itakochōshi hensaniinkai 潮来町史編さん委員会. 1996. Itakochōshi 潮来町史 (History of Itako Town). Itako: Itakochō.

Itokawa, Takashi 糸川崇. 2017. "Hitachi no kuni kashima guuke kanomukai iseki to kashima jingū 常陸国鹿島郡家（神野向遺跡と鹿島神宮）(Kashima District Office of Hitachi Province: the Kanomukai Site and the Kashima Grand Shrine).”In Kodai tōgoku no chibōo kanga to jiin 古代東国の地方官衙 と寺院 (Ancient District Offices and Temples in Eastern Japan), edited by Satō Makoto 佐藤信, 133-42. Tokyo: Yamakawa shuppansha.

Kashima City Board of Education 鹿嶋市教育委員会and Culture and Sports Kashima City Promotion Foundation 鹿嶋市文化スポーツ振興事業 団. 2016. Heisei 28 nendo kunishitei shiseki kashimajingū keidai tsuketari gūke ato genchi setsumeikai siryō 平成28年度国指定史跡鹿島神宮境 内附郡家跡現地説明会資料. Accessed June 10, 2018. http://kashimashi. info/bunkazai/wp-content/uploads/2016/12/\%E7\%8F\%BE\%E5\%9C\%B0 \%E8\%AA\%AC\%E6\%98\%8E\%E4\%BC\%9A\%E5\%BD\%93\%E6\%97\%A5 \%Е9\%85\%8D\%E5\%B8\%83\%E8\%B3\%87\%E6\%96\%99\%EF\%BC\%88HP\%E5\%85\%AC\%E9\%96\%8B\%E7\%94\%A8\%EF\%BC\%89.pdf.

Kashima-Shinryū Federation of Martial Sciences 鹿島神流武道連盟. Accessed June 10, 2018. http://www.kashima-shinryu.jp/English/index.html.

Kawai, Shōichi 川井正一. 1985. “Kanoko iseki: emishi seitō no tameno hitachi kokuga kōbō ato 鹿の子遺跡 : 蝦夷征討のための常陸国衙工房跡 (The Kanoko C Site: Official Workshops Attached to Hitachi Provincial Governor's Office)." Etonosu 28: 128-38. 
Kawai, Shōichi 川井正一, and Masayoshi Satō 佐藤正好. 1983. Kanoko C iseki 鹿の子C遺跡 (Excavation Report of the Kanoko C Site). Mito: Ibaraki prefectural foundation for Education.

Kawamata, Kiyoaki 川又清明. 2014. “Ibarakiken ni okeru kodai no seien doki shūsei 茨城県における古代の製塩土器集成 (Ancient Salt Pottery in Ibaraki Prefecture." Ibaraki kenritsureki shikanpō 41: 1-32.

Kawashima, Takamune. 2015. "Prehistoric Salt Production in Japan”. In Archaeology of Salt. Approach to an Invisible Past, edited by Robin Brigand and Olivier Weller, 125-38. Leiden: Sidestone Press.

. "Archaeology of Salt in Japan." In Encyclopedia of Global Archaeology, edited by Claire Smith. 2nd edition. New York: Springer-Verlag New York. (in press).

Ozawa, Shigeo 小沢重雄. 1994. “Hitachi ni okeru seitetsu 常陸における製鉄 (Iron manufacture in Hitachi)." In Fudoki no kōkogaku 1 Hitachinokuni fudoki no maki 風土記の考古学 1 常陸国風土記の巻 (Archaeological Study of Fudoki, 1 Hitachinokuni Fudoki), edited by Masahiro Mogi 茂木雅博, 221-43. Tokyo: Dōseisha.

Seki, Fumitake 關文威. 2015. "Kashima shinden no 'kashima no tachi' to 'futsu-no-mitama no hōsoku’ 鹿島神傳の”鹿島の太刀”と”犃霊の法則”.” Kashima shinryū budō remmei kaihōō 72 (1): 1-8.

Shirai, Kumiko 白井久美子.2013. “Kantō no kōki shūmatsuki kofun 関東の後期・ 終末期古墳 (Mounded Tombs of the Late and the Final Kofun Periods in the Kanto district).”In Kofun kara jiin he: kantō no 7 seiki wo kangaeru 古墳から寺院 へ〜関東の7世紀を考える〜 (From Mounded Tombs to Temples: Reconsideration of the Kanto District in the 7th Century), edited by Saburō Kobayashi 小 林三郎 and Kenichi Sasaki 佐々木憲一, 28-56. Tokyo: Rokuichishobō.

Tao, Masatoshi 田尾誠敏. 2009. “Kantō chihō ni okeru kodai seiendoki: tokuni taiheiyo enganbu wo chūshin ni 関東地方における古代製塩土器一特に 太平洋沿岸部を中心に一-(Ancient Salt Pottery in the Kanto District).”In Hibi no kōkogaku 2, edited by Tōkaidaigaku kōkogaku kenkyūshitsu kaisetu 20 shūnen kinen ronbunshū henshū iinkai 東海大学考古学研究室開設20 周年記念論文集編集委員会, 299-318. Tokyo: Rokuichishobō.

Watanabe, Makoto 渡辺誠. 1994. “Moshioyaki kō 藻塩焼考.”In Fudoki no kōkogaku 1 Hitachinokuni fudoki no Maki 風土記の考古学 1 常陸国風土記の巻 (Archaeological Study of Fudoki, 1 Hitachinokuni Fudoki), edited by Masahiro Mogi 茂木雅博, 101-19. Tokyo: Dōseisha.

Yamaji, Naomitsu 山路直充. 2013. “Ryūkakuji no sōken 龍角寺の創建.” In Kofun kara jiin he: kantō no 7 seiki wo kangaeru 古墳から寺院へ〜関東の7世 紀を考える〜 (From Mounded Tombs to Temples: Reconsideration of the Kanto District in the 7th Century), edited by Saburō Kobayashi 小林三郎 and Kenichi Sasaki 佐々木憲一, 140-66. Tokyo: Rokuichishobō. 
一. 山路直充. 2017. “Katori no umi wo meguru jisha to kanga 香取の海をめ ぐる寺社と郡家 (Temples and Shrines around the Katori Bay).” In Kodai tōgoku no chibō kanga to jiin 古代東国の地方官衙と寺院 (Ancient District Offices and Temples in Eastern Japan), edited by Satō Makoto 佐藤信, 109-21. Tokyo: Yamakawa shuppansha. 